\title{
DEMOGRAPHIC FACTORS AND EMPLOYEE PERFORMANCE: THE MEDIATING EFFECT OF EMPLOYEE EMPOWERMENT
}

\author{
Arief Tukiman Hendrawijaya \\ Faculty of Teacher Training and Education, Universitas Jember \\ Email:ath.wijaya@gmail.com
}

Received: January 2019; Accepted: May 2019; Available online: July 2019

\begin{abstract}
This study analyzes the influence of age, gender, education, years of service, and number of family dependents on employee empowerment both directly and indirectly through employee performance. The sample was taken from 14 cigar companies in Jember Regency, East Java, Indonesia, of which each company is represented by ten respondents who are randomly selected. The samples consist of 140 people. The study uses path analysis to determine the direct and indirect effects of the variables. The results showed that age, sex, education, years of service, and number of family dependents have a significant positive effect on employee performance and on employee empowerment. Employee performance mediates the effect of age, sex, education, years of service, and number of family dependents on employee empowerment.
\end{abstract}

Keywords: Demographic Indicators, Performance, Employee Empowerment.

\begin{abstract}
Abstrak
Penelitian ini menganalisis pengaruh usia, jenis kelamin, pendidikan, masa kerja, dan jumlah tanggungan keluarga terhadap pemberdayaan karyawan baik secara langsung maupun tidak langsung melalui kinerja karyawan. Sampel diambil dari 14 perusahaan cerutu di Kabupaten Jember, Jawa Timur, Indonesia, yang masing-masing perusahaan diwakili oleh sepuluh responden yang dipilih secara acak. Sampel terdiri atas 140 orang. Penelitian ini menggunakan analisis jalur untuk menentukan efek langsung dan tidak langsung dari variabel-variabel penelitian. Hasil penelitian menunjukkan bahwa usia, jenis kelamin, pendidikan, masa kerja, dan jumlah tanggungan keluarga memiliki pengaruh positif signifikan terhadap kinerja karyawan dan pemberdayaan karyawan. Kinerja karyawan memediasi pengaruh usia, jenis kelamin, pendidikan, masa kerja, dan jumlah tanggungan keluarga pada pemberdayaan karyawan.
\end{abstract}

Kata kunci: Indikator Demografis, Kinerja, Pemberdayaan Karyawan.

How to Cite: Hendrawijaya, A. T. (2019). Demographic Factors and Employee Performance: The Mediating Effect of Employee Empowerment. Media Ekonomi dan Manajemen, 34(2), 116-136. 


\section{INTRODUCTION}

Employee performance has played an important role and as a determinant for the success of a company. One of the determinants of employee performance is employee biographical factors which are factors inherent in each individual employee. Employees contribute to the success of the organization. For this reason, it requires employees who have a constructive and active attitude, such as high responsiveness, initiative and creativity, and adaptive sensitivity, all of which can be used as a means to increase employee productivity. Previous studies have examined the relationship between demographic aspects and employee job satisfaction (Bashir, Jianqiao, Jun, Ghazanfar, and Khan, 2011), employee performance (Baijal, 2015), academic performance (Takur, 2017), and teaching performance (Sankar, 2018). The demographic factors that have been examined include age, gender, education, tenure or working experience, and number of family dependents. These factors are discussed in more detail in the following paragraphs.

As a factor that determines a person's performance, age will affect a person's performance depending on the type of work (Warr, 1994). Age affects learning and produces better performance (Gawi, 2012). Older employees perform better than the young ones (Heck, Rowe, and Owen, 1995). Orser and Foster (1992) also report that older employees produce larger outputs than younger ones.

Gender is also a factor that can determine employee performance as a result of physical and psychological differences. Kimmel (2000) suggests that gender differences do not apply today. Men and women are treated equally in almost all sectors (Moore, 1999). Both men and women compete to get equal work positions. Business globalization provides equal opportunities for each individual to work in a company. Female workers are relatively more productive than male counterparts (Kotur and Anbazhagan, 2014).

Education influences employee performance. Education is a means to obtain quality human resources. Education is considered capable of producing highquality labor, has a modern mindset and way of acting. The high and low level of education of an employee will affect performance. Employees who do not have a working period or experience will be different from employees who already have enough years of service. Education is positively related to job performance among teachers in Nigeria (Gede and Lawanson, 2011) and among insurance policy salesmen in Lagos (Hassan and Ogunkoya, 2014)

Work period is a unit of time in which employees are actively involved in a company and reflect employee work loyalty in a workplace company, in addition to working period also often called seniority is a number of periods of continuous employee work in a company (Marisa and Sonia, 2005). The working period is related to the level of individual mastery over the implementation of the technical aspects of the work that determines whether or not an employee is experienced. Kaymakç and Babacan (2014) report that longer employment is associated with positive performance. The higher the working period of someone, the higher the psychological empowerment will be (Dickson and Lorenz, 2009). Ozaralli (2003) finds that employees who have a longer service life in the company will feel more empowered than short work periods. Kaymakç and Babacan (2014) document that employee's managerial level employees pose a greater mean for all dimensions than general administrative services and supportive services employees.

The number of family dependents is the number of family members that are borne by an employee who works. The number of family dependents consists of wife, husband and child. The more the 
number of dependents on the family, the greater the needs that must be met, so that the income received must be sufficient for life. Family dependents is the significant predictor for job performance among school teachers in Pakistan (Hanif, Tariq, and Nadeem, 2011). However, Meenakshi (2017) does not find significant relationship between family dependents and level of salary among non-governmental university workers in India or among female health care professionals in India (Ravichandran and Indumathy, 2018).

Employee empowerment is related with organization performance, and thus employee performance. Study has shown that employees with greater empowerment have higher motivation, higher job satisfaction, lower job stress, greater involvement and organizational commitment (Menon, 2001). Spreitzer (1995) show it is seen that empowered employees feel supported by their organization, have access to information and resources and have opportunity to participate. Employees having strong empowerment are perceived to be more effective and tend to be more innovative, creative and brave in trying somethings new.

In addition, there is also a relationship between demographic factors and employee empowerment. For example, Baijal (2015) finds that age and education are related to employee empowerment, but not for gender. However, in relation to employee empowerment, Zani and Pietrantoni (2001) show that women scored higher than men in meaningfulness and competence among health professionals working with mentally disabled people in Bologna, Italy. Samad and Yusuf (2014) find that age and working experience are positively related to employee empowerment among medical doctors in Malaysia. Rajasekar, Sudheer, and Reddy (2017) document that gender, age, and job tenure are related with employee empowerment. Al-Kahtani (2012) finds that age, marital status and number of dependents has a positive and significant relationship with organizational commitment.

There are numerous evidences suggesting that employee empowerment affects employee performance. For example, Iqbal, Ahmad, and Javaid (2013) find that employee empowerment has a positive significant effect on employee performance among 150 bankers of Dera Ghazi Khan District in Pakistan. Ukil (2016) show that employee empowerment determines employee satisfaction and service quality significantly among 240 working in 20 different financial institutions in Bangladesh. Yilmaz (2015) finds a positive effect of empowerment aspects on employee performance among 230 front-line employees in Turkey. However, Bose (2018) does not find significant relationship between employee empowerment and employee performance among employees in the banking industry of the United Arab Emirate.

Given the aforementioned explanation, we argue that some demographic factors are related to employee's empowerment. These factors are also associated with employee performance. Employee empowerment affects employee performance. Thus, there must be a relationship between employee's demographic factors and their empowerment and performance.

The purpose of this study was to analyze the effect of demographic factors that include age, sex, education, years of service, and the number of family dependents on employee performance. The study also examines whether employee empowerment mediates the effect of these demographic factors on employee performance. Using a total of 140 employees working in ten different cigar companies, the study documents that all the predicted relationships are accepted. Employee empowerment mediates the effect of demographic factors on employee performance. 


\section{LITERATURE REVIEW}

Employee performance is a very important thing in the company's efforts to achieve its goals (Rivai, 2006:309). According to Robbins (2006: 260), employee performance can be measured by six indicators, namely quality of work (employee perceptions of the quality of work produced and task perfection of employee skills and abilities), quantity of work (the amount produced is expressed in terms such as number of units, number of cycles of activities completed), timeliness (activity level completed by minimizing time), work effectiveness (level of use of company resources maximized with the intention of increasing yield), independence (the ability of employees to work alone in carrying out their work functions), and work commitment (level employee responsibility towards the company).

Age is the length of time a person lives from birth. Old people will work no more effectively than younger people, especially in carrying out certain tasks (Gelderblom, 2006). The body of a young person is certainly stronger than someone who is older in carrying out certain jobs given by the company. However, in certain tasks, parents can perform better than younger people. This is due to experience factors, for example in terms of giving advice that is better than younger ones.

Changes in work performance vary according to employee age. If the work requires heavy physical work or a quick reaction, then age can be a weakness, but what is required is expertise or age experience to be an advantage in improving performance related to the tasks assigned (Warr, 1994). Ilmarinen (1999) and Capanni, Sartori, Carpentiero, and Costa (2005) found that in heavy physical work, a decrease in employee performance will run earlier than a job that is mentally demanding.

Modern society has removed the boundary between lifestyles that distinguish sex between men and women.
Men and women today are far more equal compared to a few decades ago (Kimmel, 2000). Moore (1999) distinguishes between traditions (i.e., women with traditional values, adhering to stereotypical women's work roles) and modern society (i.e., next generation women who are more similar to, than different from their male counterparts). Since childhood, men and women have been treated equally in almost all walks of life and society has not prioritized one sex. Until the early 1990s research on women's entrepreneurship identified gender differences with respect to individual characteristics.

There are striking differences both physically and psychologically between men and women. This difference can cause the way men and women function at a job with the same level of efficiency. According to Goleman (1995), men and women are psychologically different. Some studies on employee performance based on gender differences find that there are striking differences between male and female employees (Brush, 1992). Fischer, Reuber, and Dyke (1993) show that gender also does not fully determine one's role. Ahl (2002) proves that there is no difference in the productivity of men and women. Bem (1993) and Korabik, Lero, and Whitehead (2008) find that gender differences (masculinity or femininity) are based on differences in social experience.

Education is defined as a human effort to foster his personality in accordance with the values in society and culture. Furthermore, education is also interpreted as an effort carried out by someone or a group of other people to become adults or achieve a higher level of life or livelihood in the mental sense. In general education is a conscious and planned effort to create a learning atmosphere and learning process so that students actively develop their potential to have religious spiritual strength, selfcontrol, personality, intelligence, noble character, and skills needed by themselves, society, and the nation. 
Every organization certainly wants its employees to continue working during their working period. This is important enough to maintain the survival of the organization. Marisa and Sonia (2005), define work period as a period of time where a person is actively involved in an organization and reflects the loyalty of the workforce in an institution where he works, while the period of work also often called seniority is a number of periods of continuous employee work an organization. Workforce placement by human resource management is very influential in achieving organizational goals. Therefore, the human resources department must be careful in choosing a workforce that is truly in accordance with the work to be given. If the workforce placed can work well, the overall performance of the company will be optimal. Basically, every individual in each organization has the ability, intelligence, skills, and potential that can change and develop over time.

The number of family dependents is the number of family members that are borne by an employee who works. With the increasing number of family dependents, the greater the needs that must be met, so that the income received is insufficient to meet the needs of life and is in a state of imbalance or poverty. This family dependency is also one of the main reasons for women in a household to participate in helping their partners decide to work to supplement their income.

Several studies on employee performance have been conducted, previous studies have shown different results and are still a debate among academics' practitioners. Factors that influence employee performance are education and training, discipline, attitudes and work activities, work morale. Khuong and Yen (2016) and Dinc and Plakalovic (2016) find that commitment is a factor that can affect employee performance. Whereas Clifford and Gerasmus (1997) show that job satisfaction affects performance.

\section{Hypotheses Development}

Increasing age will have its own consequences for all sectors related to employee empowerment which include the health sector, economic, social, cultural and other sectors. Therefore, increasing age needs to be anticipated, starting from sectors to prepare comprehensive employee empowerment. Age is a determinant of individual performance that will vary between persons depending on their work difficulty (Warr, 1994). When faced with more physical demanding type of job, older people are assumed to be less competitive than the younger ones. Interestingly, Orser and Foster (1992) report that business owners aged 40 years and over have the opportunity to produce more than those who were less than 40 years old. However, other studies conclude that there is no significant difference between sales performance and business actors' age (Fauzilah, 2012). Robbins and Judge (2008) reveal that separating between professionals and nonprofessionals show that performance levels tend to increase in professionals with increasing age, while in non-professionals performance decreases with age. Increasing age will also increase the wisdom of one's ability to make decisions, think rationally, control emotions, and tolerate the views of others, so that it influences the increase in performance.

Empirical evidence suggests that age is related to employee performance. Gawi (2012) finds that age affects learning and produces better performance. Even Heck, Rowe, and Owen (1995) documents older employees perform better than the young ones. Older employees produce larger outputs than younger ones (Orser and Foster, 1992). Rajalingam, Jauhar, and Bashawir (2015) find strong evidence that employee empowerment positively affects employee performance among 200 workers from a major manufacturing company in Seberang Prai, Malaysia.

Based on the description above, the hypotheses proposed are: 
$\mathrm{H}_{1.1}$ : Age affects employee empowerment. $\mathrm{H}_{1.2}$ : Age affects employee performance.

$\mathrm{H}_{1.3}$ : Employee empowerment mediates the effect of age on employee performance.

Robbins and Judge (2008) state that men are more aggressive and more likely to have stronger hope for success, so that men are better performing than women. Ivancevich, Konopaske, and Matteson (2011) advocate that most stereotypical differences that are often used to describe men and women in organizations are actually invalid. This is supported by several studies that find no difference between men and women in performance on medical student examinations (Holmes, Holmes and Hassanein, 1978). Interestingly, Plauché and Miller (1986) report that female students outperform men in both clinical evaluation and written examination. Fauzilah (2012) does not find significant difference between sales performance and gender of business people. Whereas Inmyxai and Takahashi (2010), comparing the performance of companies led by men or women and the results reveal differences in performance between companies led by men and women.

Kimmel (2000) argues that gender differences do not apply today. Men and women are treated equally in almost all sectors (Moore, 1999). Globalization has provided equal opportunities for each individual to get employed in an organization. In other words, either men or women must compete each other to get equal work positions. Previous studies have tried to examine the effect of gender on employee performance and employee empowerment. For example, Sankar 92018) reports that female professionals are possessing better employee empowerment than the male respondents. Kotur and Anbazhagan (2014) finds that female workers are relatively more productive than male counterparts. Badal and Harter (2014) show that independently, at the business-unit level, gender diversity predicts financial performance. Interestingly, Hoogendoorn Oosterbeek, and Van Praag (2013) document than the mixed gender performs better than maledominated teams. Kariuki and Wekesa (2018) find strong evidence showing that employee empowerment positively related to the performance.

Based on the description above, the proposed hypotheses are:

$\mathrm{H}_{2.1}$ : Gender influences employee empowerment.

$\mathrm{H}_{2.2}$ : Gender influences employee performance.

$\mathrm{H}_{2.3}$ : Employee empowerment mediates the effect of gender on employee performance.

For a company, empowerment will improve individual performance so that employees can develop their talents in full. Employees master new understanding and skills and provide opportunities to see things differently, reflecting what is seen and developing these skills (Pratama, Bahtera, Anggara, and Yolanda, 2010). According to Benson, Finegold, and Mohrman (2004), there are many companies that use education as an indicator of a person's skill or productivity level and often use it as a prerequisite in deciding decisions. Employees with higher education only contribute little to the effectiveness of the organization than do educated workers, so the higher costs of placing staff with highly educated workers are not possible (Benson et al., 2004).

Empowerment starts from ourselves, then also needs to empower our children and realize the importance of the same education. Early on they must know and learn that they are the same. Armed with this education they will later shape their views on their respective positions both from the household, the world of work, and society. Employee empowerment carried out will be able to direct the employee to always prioritize education. Especially education for children both formal, non- 
formal and informal, so that the employee is able to change their thinking that education is important in accordance with the theory above.

Based on the description above, the proposed hypotheses are:

$\mathrm{H}_{3.1}$ : Education affects employee empowerment.

$\mathrm{H}_{3.2}$ : Education affects employee performance.

$\mathrm{H}_{3.3}$ : Employee empowerment mediates the effect of education on employee performance.

Dickson and Lorenz (2009) posit that an increase in work period will also be accompanied by an increase in competence. Someone who has a high working period indicates that one's expertise will also be more adequate. Psychologically, the ability of employees consists of the ability of potential and ability of reality. That is, employees who have above average abilities with adequate education or knowledge to carry out jobs that are skilled in doing daily work, then he will more easily achieve the expected achievements. Marisa and Sonia (2005) define the working period as a period of time in which a person is actively involved in a company and reflects the loyalty of the workforce in an institution where he works. A longer working period will make a person perform better and be more reliable. Evidence of the relationship between tenure and performance can be found in professions that require special knowledge and experience (Van Vugt, 2006). Mujtaba and Kaifi (2008) asert that leaders have a higher value of relationship orientation closely related to better performance. This means that with some special knowledge or skills can appear better as a leader. Nsubuga (2009) claims that education and experience bring changes to the principal's leadership and performance attitudes. Cagle (1988) has considered experience and education as factors that determine the style and performance of leadership more expe- rienced and qualified. Nsubuga (2009) also added that with knowledge and skills in management and leadership, principals would be effective at work. Katozai (2005) argues that knowledge is the main weapon that makes a leader work more effectively, therefore leaders get a better education.

The higher working period will also be followed by increasing selfdetermination. On various occasions, local employees are often involved in organizational activities. They are also given the right of autonomy in completing tasks that have been delegated to him. Bosses do not necessarily control subordinates continuously, but still carry out supervision so that the implementation of tasks goes according to the established corridor. Bosses act as coaches and mentors. Employees are given the freedom to determine the workings of completion of tasks accompanied by responsibility for the results of operations. Self-determination is the feeling of someone who has the opportunity to use initiative and regulate behavior in doing their work (Spreitzer, Kizilos and Nason, 1997).

Based on the description above, the proposed hypotheses are:

$\mathrm{H}_{4.1}$ : Tenure has an effect on employee empowerment.

$\mathrm{H}_{4.2}$ : Tenure has an effect on employee performance.

$\mathrm{H}_{4.3}$ : Employee empowerment mediates the effect of tenure on employee performance.

The number of family dependents is the number of family members who live in one house and have not worked who are dependent on the household. The more the number of family members the greater the needs met, so that there is insufficient income to meet their needs and the family is in a state of imbalance or poverty. Family dependence is one of the main reasons for household women to participate in helping husbands to decide to work for income. The more respondents have children and dependents, the more 
time the respondent provides to work more effectively.

Encouraged by someone entering the labor market due to the condition of the economy of a household that is in short supply with a large number of dependents, the husband's income is insufficient to finance the children's needs so women will tend to make a living without neglecting their household duties. Increased family income can be realized through the contribution of male and female family members. Income is the total income received by workers or households, both physical and non-physical during work or business. That income can later be used as a means of fulfilling needs.

The number of family members greatly determines the number of family needs. The larger the number of family members, the higher is the needs of meeting the daily consumption. So, in families with a large number of members, there is also larger efforts required to meet the needs. Previous studies find mixed results on the effect of the number of dependents on performance of employees. Hanif et al. (2011) find that family dependents is a significant determinant for job performance among school teachers in Pakistan. Nevertheless, there is no significant relationship between family dependents and level of salary among female health care professionals in India (Ravichandran and Indumathy, 2018) or among non-governmental university workers in India Meenakshi (2017).
Based on the description above, the proposed hypotheses are:

$\mathrm{H}_{5.1}$ : The number of family dependents affects employee performance.

$\mathrm{H}_{5.2}$ : The number of family dependents influences employee empowerment.

$\mathrm{H}_{5.3}$ : Employee empowerment mediates the effect of the number of family dependents on employee performance.

Empowering employee means motivating employees to be more involved in making decisions and activities that affect their work. That means that empowerment gives employees the opportunity to show that they are able to be trusted. Empowerment is also related to the distribution of responsibilities. For a company, empowerment will improve individual performance so that employees can develop their talents in full. Employees master new understanding and skills and provide opportunities to see things differently, reflecting what is seen and developing these skills. Previous studies find a positive effect of employee empowerment on employee performance (Iqbal et al., 2013, Ukil, 2016; Yilmaz, 2015).

Based on the description above, the proposed hypothesis is:

$\mathrm{H}_{6}$ : Employee empowerment influences employee performance.

Figure 1 depicts the frameworks and the research proposed hypotheses. 


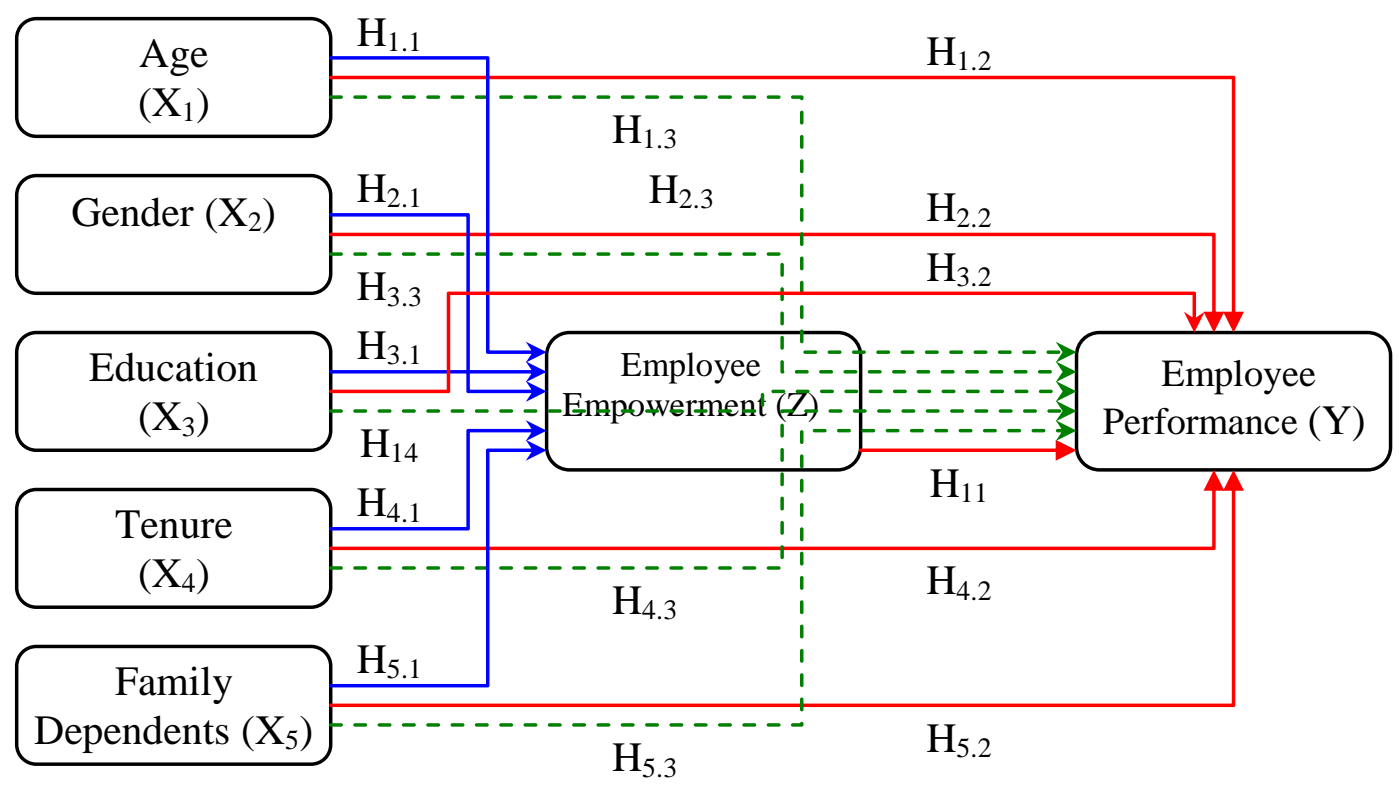

Figure 1. Conceptual Framework of the Study

\section{RESEARCH METHODS}

The population of this study were all 14 companies in the cigar processing company in Jember Regency. The research sample was determined using the stratified random sampling method. Ten companies were randomly selected and ten people from each company were chosen as the research respondents. The respondents were randomly selected. All research respondents totaled 140 respondents. The focus of this study leads to efforts to find the effect of age, sex, education, years of service and number of family dependents on employee empowerment directly and indirectly through the performance of employees of cigar processing companies in Jember Regency.

The main data (primary data) is collected using a questionnaire (questionnaire) as the main method. Data collection techniques by the way respondents fill out questionnaires and interviews conducted by researchers. The completion of the questionnaire (data collection) is carried out from April to July 2018.

The research questionnaire used was a five-point Likert scale adapted from the literature. Measurements on age and sex were obtained from the age of the respondent when the study was conducted which was then categorized into $<20$ years with a category of value 1, 20-29 years with a value category of 2, 30-39 years with a value category of 3 and 40 years with a value category 4 while the respondent's sex based on the Identity Card data of the respondent which includes male sex is categorized by value 1 and women are categorized by value 2 . The measurement of respondent's education is the last education of the respondents which is then categorized as SD / equivalent with category 1 , SLTP / equivalent with a value category of 2, high school / equivalent with a value category of 3 and a college with a value category of 4 . The length of service is obtained from the length of time the respondent worked at the time of the study, then categorized into $<2$ years with a value of 1, 2-5 years with grades 2, 6-10 years with grades 3 and more than 10 years with grades 4 . The measurement of employee performance variables is an endogenous variable, the measurement of performance variables adopts a questionnaire developed by Osborn and Gabler (1992), Micheli and Neely (2010), and Jankingthong and Rurkkhum (2013). The measurement of the employee empowerment variable adopts an empowerment index developed by Hashemi, Schuler, and Riley (1996). 
The data analysis method used is path analysis to determine the effect of age, sex, education, years of service and the number of family dependents on employee empowerment with employee performance variables as mediating variables. The results of this analysis can be seen direct effect, indirect influence (through employee performance) and total influence.

\section{RESULT AND DISCUSSION}

\section{Respondents General Description}

The population in this study were employees of cigar processing companies in Jember Regency, while the sample of this study was taken from all cigar processing companies in Jember Regency which numbered 14 companies and each company selected 10 respondents, so the number of samples was 140 respondents. Questionnaires were distributed directly to respondents and the results were analyzed as research data. Data on respondents' characteristics included: age, gender, education, years of service and number of family dependents. The characteristics of the respondents in this study are presented in Table 1.

Table 1. General Description of Respondents

\begin{tabular}{|c|c|c|c|}
\hline \multirow{2}{*}{ Characteristic } & \multirow{2}{*}{ Description } & \multicolumn{2}{|c|}{ Distribution } \\
\hline & & Frequency & Percentage $(\%)$ \\
\hline \multirow[t]{4}{*}{ Age } & Less than 20 year & 6 & .0 \\
\hline & 20-29 year & 59 & 42.1 \\
\hline & 30-39 year & 73 & 52.1 \\
\hline & More than 40 year & 2 & 1.4 \\
\hline \multirow[t]{2}{*}{ Gender } & Male & 32 & 22.9 \\
\hline & Female & 108 & 77.1 \\
\hline \multirow[t]{3}{*}{ Education } & Elementary School & 94 & 67.1 \\
\hline & Junior High School & 31 & 22.1 \\
\hline & Senior High School & 13 & 10.7 \\
\hline \multirow[t]{4}{*}{ Tenure } & Less than 2 year & 11 & 7.9 \\
\hline & $2-5$ year & 19 & 13.6 \\
\hline & 6-10 year & 39 & 27.9 \\
\hline & More than 10 year & 71 & 50.7 \\
\hline \multirow[t]{4}{*}{ Number of Family Dependents } & 1 people & 13 & 9.3 \\
\hline & 2 people & 24 & 17.1 \\
\hline & 3 people & 82 & 58.6 \\
\hline & 4 people & 21 & 15.0 \\
\hline Total & & 140 & 100 \\
\hline
\end{tabular}

Table 1 shows that the majority of respondents are in the range of 30-39 years, which is as many as 73 respondents $(52.1 \%)$. Most of the respondents were female, i.e., 108 respondents (77.1\%). This is not surprising as it is common that the employees of the Cigar Company are dominated by women. Women are perceived to be a painstaking worker. Based on education, the majority of respondents only had the last primary education or equivalent, with a total of 94 respondents $(67.1 \%)$. This is also very common that the Cigar Company does not require well educated workers as the workers' main duty is selecting and chopping tobacco. Most respondents worked in cigar processing companies for 10 years or more $(50.7 \%$ or as many as 71 respondents). The data show that half of the workers are having relatively good working experience and they expected to be able to give better judgment on the provided questionnaires. While about the 
number of family dependents, most of the respondents have family dependents of at least three people, (82 respondents or $58.6 \%$ ). The data indicate that the workers have to feed relatively large number of dependents.

\section{Data Analysis and Hypothesis Testing}

The results of the calculation of the direct effect obtained by the path coefficient value between variables age, sex, education, years of service and number of family dependents on endogenous performance variables and the value of the path coefficient between performance variables and employee empowerment. The value of the path coefficient of the direct influence between variables in the research model is presented in Table 2.

Table 2. Results of Direct Test

\begin{tabular}{llcccr}
\hline Hyp. & \multicolumn{1}{c}{ Regression Model } & $\begin{array}{c}\text { Regression } \\
\text { Coefficient }\end{array}$ & $\begin{array}{c}\text { Path } \\
\text { Coefficient }\end{array}$ & t-stat & p-value \\
\hline $\mathrm{H}_{1.1}$ & Age $\left(\mathrm{X}_{1}\right) \rightarrow$ Employee Empowerment $(\mathrm{Z})$ & 2.292 & 0.204 & $2.743^{* *}$ & 0.007 \\
\hline $\mathrm{H}_{2.1}$ & Gender $\left(\mathrm{X}_{2}\right) \rightarrow$ Employee Empowerment $(\mathrm{Z})$ & 2.431 & 0.150 & $2.024^{*}$ & 0.045 \\
\hline $\mathrm{H}_{3.1}$ & Education $\left(\mathrm{X}_{3}\right) \rightarrow$ Employee Empowerment $(\mathrm{Z})$ & 4.420 & 0.442 & $8.501^{* *}$ & 0.000 \\
\hline $\mathrm{H}_{4.1}$ & Tenure $\left(\mathrm{X}_{4}\right) \rightarrow$ Employee Empowerment $(\mathrm{Z})$ & 1.054 & 0.148 & $2.025^{*}$ & 0.045 \\
\hline $\mathrm{H}_{5.1}$ & Family dependents $\left(\mathrm{X}_{5}\right) \rightarrow$ Employee Empowerment $(\mathrm{Z})$ & 4.374 & 0.520 & $6.180^{* *}$ & 0.000 \\
\hline $\mathrm{H}_{1.2}$ & Age $\left(\mathrm{X}_{1}\right) \rightarrow$ Employee Performance $(\mathrm{Y})$ & 1.193 & 0.148 & $1.990^{*}$ & 0.049 \\
\hline $\mathrm{H}_{2.2}$ & Gender $\left(\mathrm{X}_{2}\right) \rightarrow$ Employee Performance $(\mathrm{Y})$ & 2.453 & 0.212 & $2.882 * *$ & 0.005 \\
\hline $\mathrm{H}_{3.2}$ & Education $\left(\mathrm{X}_{3}\right) \rightarrow$ Employee Performance $(\mathrm{Y})$ & 1.338 & 0.187 & $2.156 *$ & 0.033 \\
\hline $\mathrm{H}_{4.2}$ & Tenure $\left(\mathrm{X}_{4}\right) \rightarrow$ Employee Performance $(\mathrm{Y})$ & 0.736 & 0.145 & $1.995^{*}$ & 0.048 \\
\hline $\mathrm{H}_{5.2}$ & Family dependents $\left(\mathrm{X}_{5}\right) \rightarrow$ Employee Performance $(\mathrm{Y})$ & 1.266 & 0.210 & $2.260^{*}$ & 0.025 \\
\hline $\mathrm{H}_{6}$ & Performance $(\mathrm{Z}) \rightarrow$ Employee Performance $(\mathrm{Y})$ & 0.243 & 0.340 & $4.038^{* *}$ & 0.000 \\
\hline
\end{tabular}

Indirect influence is the influence of an exogenous variable on endogenous variables that occurs through other endogenous variables contained in a causal model. The magnitude of the indirect effect of an exogenous variable on endogenous variables is the multiplication of the value of exogenous path coefficients on endogenous variables with the value of the endogenous variable path coefficient on other endogenous variables (Roflin, 2009). The path coefficient value of the indirect influence between variables in the research model and the results of testing the significance of indirect effects are presented in Table 3.

Table 3. Results of Indirect Effect Test

\begin{tabular}{clccc}
\hline Hypothesis & \multicolumn{1}{c}{ Regression Model } & $\begin{array}{c}\text { Indirect } \\
\text { Effect }\end{array}$ & t-value. & p-value. \\
\hline $\mathrm{H}_{1.3}$ & $\begin{array}{l}\text { Age }\left(\mathrm{X}_{1}\right) \rightarrow \text { Employee Empowerment }(\mathrm{Z}) \rightarrow \text { Employee } \\
\text { Performance }(\mathrm{Y})\end{array}$ & 0.069 & 2.269 & $0.026 *$ \\
\hline $\mathrm{H}_{2.3}$ & $\begin{array}{l}\text { Gender }\left(\mathrm{X}_{2}\right) \rightarrow \text { Employee Empowerment }(\mathrm{Z}) \rightarrow \text { Employee } \\
\text { Performance }(\mathrm{Y})\end{array}$ & 0.051 & 2.530 & $0.013 *$ \\
\hline $\mathrm{H}_{3.3}$ & $\begin{array}{l}\text { Education }\left(\mathrm{X}_{3}\right) \rightarrow \text { Employee Empowerment }(\mathrm{Z}) \rightarrow \text { Employee } \\
\text { Performance }(\mathrm{Y})\end{array}$ & 0.150 & 3.255 & $0.002 * *$ \\
\hline $\mathrm{H}_{4.3}$ & Tenure $\left(\mathrm{X}_{4}\right) \rightarrow$ Employee Empowerment $(\mathrm{Z}) \rightarrow$ Performance $(\mathrm{Y})$ & 0.050 & 2.675 & $0.009 * *$ \\
\hline $\mathrm{H}_{5.3}$ & $\begin{array}{l}\text { Family dependent }\left(\mathrm{X}_{5}\right) \rightarrow \text { Employee Empowerment }(\mathrm{Z}) \rightarrow \\
\text { Employee Performance }(\mathrm{Y})\end{array}$ & 0.177 & 3.381 & $0.001 * *$ \\
\hline
\end{tabular}


Based on the path coefficient value, the direct and indirect influence between exogenous variables (age, sex, education, years of service and number of family dependents) on the variable employee empowerment through performance is known to the total influence of each exogenous variable (age, sex, education, tenure and number of dependents on the employee empowerment variable). Table 4 presents the results of the direct and indirect effect of the tested variables.

Based on the table above, it is known that the total influence of the independent variables on employee empowerment is age $21.8 \%$, sex $26.3 \%$, education $33.7 \%$, work period $19.5 \%$ and number of dependents family of $38.7 \%$. In summary the results of path analysis are presented in Figure 2.

Table 4. Test Results of Direct and Indirect Effect

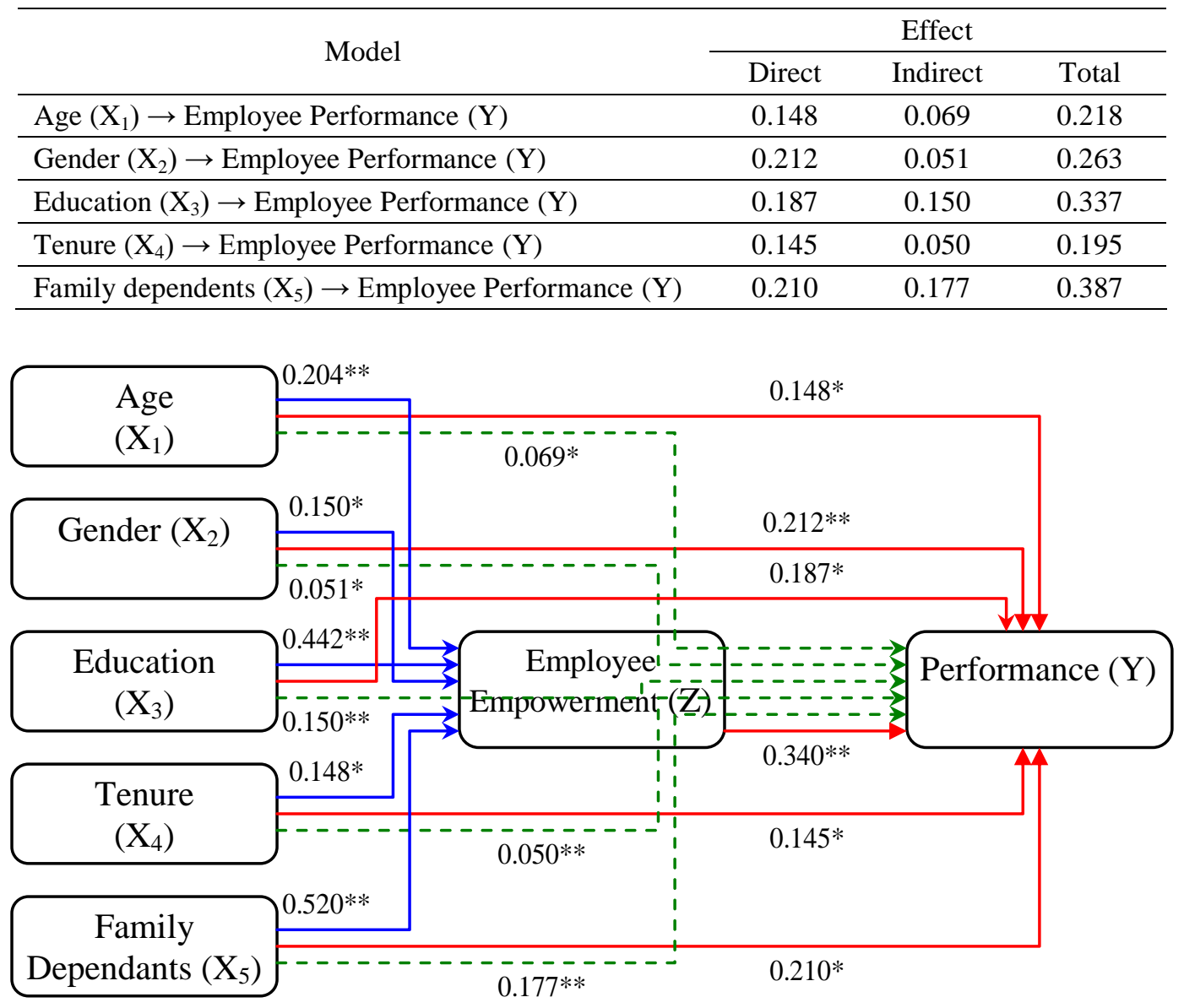

Figure 2. Path Coefficients of Direct and Indirect Effect Note: $* *, *$ denote significant at $1 \%$ and $5 \%$, respectively

\section{Discussion}

Age has a positive and significant effect on employee empowerment (accept $\mathrm{H}_{1.1}$ ) and employee performance (accept $\mathrm{H}_{1.2}$ ). For a company, empowerment will improve individual performance so that employees can develop their talents in full.
Employees master new understandings and skills and provide opportunities to see things differently, reflecting what is seen and developing these skills (Wibowo, 2010). Characteristics of an employee based on age is very significant positive effect on performance in the company, 
where the older the employee's age in accepting a job will be more responsible and experienced. Increasing age will also increase the wisdom of one's ability to make decisions, think rationally, control emotions, and tolerate the views of others, so that it influences the increase in performance.

Employee empowerment mediates the effect of age on employee performance (accept $\mathrm{H}_{1.3}$ ). The test results show that employee performance is able to mediate the influence of age on employee empowerment. For a company, empowerment will improve individual performance so that employees can develop their talents in full. Employees master new understandings and skills and provide opportunities to see things differently, reflecting what is seen and developing these skills (Wibowo, 2010).

Gender influences employee empowerment (accept $\mathrm{H}_{2.1}$ ) and employee performance (accept $\mathrm{H}_{2.2}$ ). Empowerment must start from ourselves, then also need to empower our children and realize the importance of equal education between boys and girls. Early on they must know and learn that they are the same. Armed with this education they will later shape their views on their respective positions both from the household, the world of work, and society.

This result is in line with Inmyxai and Takahashi (2010) who found that there were differences in performance between companies led by men and women, while other studies found that female students outperformed men in both clinical evaluation and written examination (Plauché and Miller, 1986) These results contradict the results of several studies which found no difference between men and women in performance in medical student examinations (Holmes et al., 1978; Fauzilah, 2012). Kotur and Anbazhagan (2014) found that age and gender influence employee performance. Employees at middle age, appear better than those who are extreme. Gender is also found to have an effect on performance and female workers are relatively more productive (Kotur and Anbazhagan, 2014).

Employee empowerment mediates the effect of gender on employee performance. The test results show that employee performance is able to mediate the influence of gender on employee empowerment.

Education has an influence on employee empowerment (accept $\mathrm{H}_{3.1}$ ) and employee performance (accept $\mathrm{H}_{3.2}$ ). Employee empowerment carried out will be able to direct the employee to always prioritize education. Especially education for children both formal, non-formal and informal, so that the employee is able to change their thinking that education is important.

This study found that education has a significant positive effect on employee performance. Education has an effect on productivity and corporate support for government subsidies for education. According to Lepak and Snell (1999), individual educational achievements are not only part of the company's human resources but are also part of the employee's core assets. In some cases, subsidies for education are largely based on the assumption that government investment in human capital will strengthen the overall economy by increasing employee productivity (Lanzi, 2007; Trusty and Niles, 2004).

Employee empowerment mediates the effect of education on employee performance (accept $\mathrm{H}_{3.3}$ ). Education is an indicator of the progress of a nation. Education is essentially a conscious effort to develop personality and abilities both inside and outside school and lasts a lifetime. The application of developing science and technology is strongly influenced by the level of formal and informal education. Education is one form of investment in human resources. Education provides a direct contribution to the growth of national income through increased skills and work productivity. 
Education is expected to overcome economic backwardness through its effect on increasing human capacity and motivation for achievement. Education serves to prepare one of the inputs in the production process, namely labor, in order to be able to work productively because of its quality. For a company, empowerment will improve individual performance so that employees can develop their talents in full.

Tenure has an effect on employee empowerment (accept $\mathrm{H}_{4.1}$ ) and employee performance (accept $\mathrm{H}_{4.2}$ ). The test results show results that support this hypothesis. A high working period indicates that the sense of impact will also increase (Dickson \& Lorenz, 2009). Someone who is empowered has a sense of impact, meaning that the person believes that they can have an influence on their work unit, and the organization wants to listen to employee ideas. People who have a long working period have sociopolitical support, which means that people who work in a work unit in a long range indicate that they will gain legitimate recognition from the organization (Kanter, 1983, in Spreitzer, 1996: 488). Even those who have a high working period are often used as role models or examples of employees who still lack work experience. Individuals who perceive sociopolitical support are high, thus contributing to increasing feelings of empowerment (Spreitzer, 1996: 498).

This study found that tenure has a significant positive effect on employee performance. A long working period will make a person perform better and therefore be reliable. At present, evidence of the relationship between knowledge, years of service and performance can still be found in professions that require special knowledge and experience (Van Vugt, 2006). The tenure will play an important role in individual performance. With more experience people will be wiser and this happens because of the long working period. According to Ahiazu (1989), in African culture, experience is considered a priority for leadership positions in various companies. Belal and Mutjaba (2010) also found that education and experience did have an impact on individual performance and it was considered very important to investigate the influence of educational experience and qualifications on employee leadership styles.

Employee empowerment mediates the effect of tenure on employee performance (accept $\mathrm{H}_{4.3}$ ). The higher working period will also be followed by increasing self-determination. On various occasions, local employees are often involved in organizational activities. They are also given the right of autonomy in completing tasks that have been delegated to him. Bosses do not necessarily control subordinates continuously, but still carry out supervision so that the implementation of tasks goes according to the established corridor. Bosses act as coaches and mentors. Employees are given the freedom to determine the workings of completion of tasks accompanied by responsibility for the results of operations. Self-determination is the feeling of someone who has the opportunity to use initiative and regulate behavior in doing their work (Spreitzer et al., 1997).

The number of family dependents influences employee empowerment (accept $\mathrm{H}_{5.1}$ ) and employee performance (accept $\mathrm{H}_{5.2}$ ). The number of family members greatly determines the number of family needs. The more family members mean the more the number of family needs that must be met. Vice versa, the fewer family members mean the fewer needs that must be met by the family. So that in families with a large number of members, it will be followed by many needs that must be met. The larger the size of the household means the more members of the household will ultimately be the heavier the burden of the household to fulfill their daily needs. Likewise, the number of children in the family and family members who are disabled or elderly will have an impact on the size of the expenditure of a family. 
They cannot afford the costs of their own lives so they depend on their family heads and wives. Children who are not yet adults need to be helped with education, health and other living expenses.

The number of family dependents had a significant positive effect on employee performance. Family dependence is one of the main reasons for household women to participate in helping husbands to decide to work for income. The more respondents have children and dependents, the more time the respondent provides to work more effectively. In addition, in this study, the number of family dependents affected employee performance, because if the number of children and dependents increased, the costs incurred for daily necessities were also higher and school fees were relatively expensive. This is the motivation of respondents to work harder with the aim of fulfilling family needs.

Employee empowerment mediates the effect of the number of family dependents on employee performance. The number of family members greatly determines the number of family needs. The more family members mean the more the number of family needs that must be met. Vice versa, the fewer family members mean the fewer needs that must be met by the family. So that in families with a large number of members, it will be followed by many needs that must be met. The larger the size of the household means the more members of the household will ultimately be the heavier the burden of the household to fulfill their daily needs. Likewise, the number of children in the family and family members who are disabled or elderly will have an impact on the size of the expenditure of a family. They cannot afford the costs of their own lives so they depend on their family heads and wives.

Employee empowerment affects employee performance (accept $\mathrm{H}_{6}$ ). The test results found that employee empowerment has a significant positive effect on employee performance.
Empowering employee means motivating employees to be more involved in making decisions and activities that affect their work. That means that empowerment gives employees the opportunity to show that they are able to be trusted. The finding of this study supports those of Rajalingam et al. (2015) and Kariuki and Wekesa (2018). In other words, this study provides strong evidence that employee empowerment positively related to the performance.

\section{CONCLUSION AND RECOMMEN- DATION}

Based on the results of research on the influence of age, sex, education, years of work and number of family dependents on employee empowerment through employee performance, it was concluded that age, sex, education, years of work and the number of family dependents influence employee empowerment both directly and indirectly through employee performance. This research was only conducted specifically at fourteen cigar processing companies in Jember Regency and further research should be conducted on employee empowerment, especially women in companies engaged in other fields so that research results can be generalized on a broader scale.

The findings of this study shall be treated with cautious as we argue that there are two likely limitations. The first is we take the indicators from western-based articles. We might argue that the understanding, culture, and knowledge of the respondents may be different that could lead to variation of responses. In other words, this study does not make adjustment to the implemented indicators. Thus, we suggest that the future study shall perform some modification on the indicators that are suitable to the local setting. Secondly, we are unaware of any bias in terms of the respondents between the cigar companies. The size of each cigar company cannot be assumed to be comparable as the real conditions show that there are different in terms of size and 
number of employees. Thus, the future study may use the one single organization that is the largest one or make comparison between one Cigar Company and another.

\section{REFERENCES}

Ahiazu, A.I. (1989). The "Theory A" system of work organization for the modern African workplace. International Studies of Management and Organization, 19(1), 6-27. Doi:10.1080/00208825.1989.116564 96.

Ahl, H.J. (2002). The making of the female entrepreneur: A discourse analysis of research texts on women's entrepreneurship. JIBS Dissertation Series 015. Jönköping University.

Al-Kahtani, N.S. (2012). A study of relationship between demographical variables, organizational structure and social interaction with organizational commitment among employees of Saudi Arab, International Journal of Trade and Commerce, 1(1), 11-22.

Badal, S., \& Harter, J.K. (2014). Gender diversity, business-unit engagement, and performance, Journal of Leadership \& Organizational Studies, 21(4), 354-365.

Baijal, A. (2015). A study on employees empowerment with the demographic variables in the employees of Union Bank of India working for Star Union Da Ichi Life Insurance, International Journal of Science and Research, 4(4), 1431-1436.

Base, A. (2018). Employee empowerment and employee performance: An empirical study on selected banks in UAE. Journal of Applied Management and Investment, 7(2), 71-82.
Bashir, M., Jianqiao, L., Jun, Z., Ghazanfar, F., \& Khan, M.M. (2011). The role of demographic factors in the relationship between high performance work system and job satisfaction: A multidimensional approach, International Journal of Business and Social Science, 2(18), 207-218.

Belal, A.K. \& Mujtaba, B.G. (2010). Transformational leadership of Afghans and Americans: A study of culture, age and gender. Journal Service Science and Management. 3(1): 150-158. Doi:10.4236/ jssm.2010.31019.

Bem, D.J. \& Berkowitz, L. 1993. Selfperception theory. Advances in Experimental Social Psychology. Vol. 6.

Benson, G.S., Finegold, D. \& Mohrman, S.A. (2004). You paid for the skills, now keep them: Tuition reimbursement and voluntary turnover. Academy of Management Journal. $\quad$ 47(1): 315-331. Doi: $10.2307 / 20159584$.

Borg, W.R. \& Gall, M.D. (2003). Educational Research: An Introduction ( $7^{\text {th }}$ ed.). New York: Longman, Inc.

Bose, I. (2018). Employee empowerment and employee performance: an empirical study on selected banks in UAE, Journal of Applied Management and Investments, 7(2), 71-78.

Brush, C.G. (1992). Research on women business owners: past trends, a new perspective and future directions. Entrepreneurship: Theory and Practice. 16 (4). Doi:10.1177/ 104225879201600401. 
Cagle, S.G. (1988). Fiedler's Contingency Theory of Leadership Effectiveness and Appointment of a Committee Chairperson. Dissertation Abstracts International. 50(07)-B: 2842.

Capanni, C., Sartori, S., Carpentiero, S.G., \& Costa, G. (2005). Work ability index in a cohort of railway construction workers. International Congress. Series 1280: 253-257.

Chambers, R. (1995). Rural Development: Putting the Last First. London, New York: Longman.

Chan, Y., Taylor, R., \& Markham, S. (2008). The role of subordinates: Trust in a social exchange-driven psychological empowerment. Journal of Managerial Issues. 20(4): 444-467.

Clifford, P. McC. \& Gerasmus, A.G. (1997). The relationship between job satisfaction and performance the case of Local Government Finance of in Ohio. Public Productivity and Management Review. 21(2): 170191. doi: $10.2307 / 3380882$.

Dessler, G. 2003. Human Resource Management. $9^{\text {th }}$ edition. New York: Prentice Hall.

Dickson, K.E. \& A. Lorenz. 2009. Psychological empowerment and job satisfaction of temporary and parttime non-standard workers: A preliminary investigation. Institute of Behavioral and Applied Management. 24(1): 166-191.

Dinc, M.S. \& Plakalovic, V. (2016). Impact of caring climate, job satisfaction, and affective commitment on employees' performance in the banking sector of Bosnia and Herzegovina. Eurasian Journal of Business and Economics. 9(18): 116. doi:10.17015/ejbe.2016.018.01.
Fauzilah, S. (2012). Demographic Characteristics Differences and Sales Performance among Night Market Traders in Malaysia. International Business Research. 5(4): 25-33. doi:10.5539/ibr.v5n4p25.

Fischer, E.M., Reuber, A.R., \& Dyke, L.S. (1993). A theoretical overview and extension of research on sex, gender and entrepreneurship. Journal of Business. 8 (2): 151-168. Doi: 10.1016/0883-9026(93)90017-Y.

Friedman, J. (1992). Empowerment: The Politics of Alternative Development. Cambridge, USA: Blackwell Publishers.

Gawi, E.M.K. (2012). The Effects of Age Factor on Learning English: A Case Study of Learning English in Saudi Schools, Saudi Arabia. English Language Teaching, 5(1), 127-139. doi:10.5539/elt.v5n1p127.

Gede, N.T., \& Lawanson, O.A. (2011). Emloyees' characteristics and job performance of staff of the bayelsa state ministry of education, Proceedings of the 2011 International Conference on Teaching, Learning and Change, International Association for Teaching and Learning (IATEL). Retrived from: www.hrmars.com/ admin/pics/163.pdf.

Gelderblom, A. (2006). In Ageing and employment: Identification of good practice to increase job opportunities and maintain older workers in employment. The relationship of age with productivity and wages, European Commission. pp. 67-84.

Gibson, J.L., Ivancevich, J.M., Donnelly Jr., J.H., \&. Konopaske, R. (2009). Organization: Behavior, Structure, Processes, $\left(14^{\text {th }}\right.$ ed.). New York: McGraw-Hill.

Goleman, D. (1995). Emotional Intelligence. New York: Bantam. 
Hanif, R., Tariq, S., \& Nadeem, M. (2011). Personal and job-related predictors of teacher stress and job performance among school teachers, Pakistan Journal of Commerce and Social Sciences, 5(2), 319-329.

Hashemi, S.M., Schuler, S.R., \& Riley, A.P. (1996). Rural credit programs and women's empowerment in Bangladesh, World Development. Elsevier Journal. 24(4): 635-653. Doi:10.1016/0305-750X(95)00159-

A.

Heck, R., Rowe, B., \& Owen, A. (1995). Home Based Employment and Family Life. Westport. Connecticut: Auburn House.

Holmes, F.F., Holmes, G.E., \& Hassanein, R. (1978). Performance of male and female medical students in a medicine clerkship. Journal of the American Medical Association. 239(1), 2259-2262. doi:10.1001/ jama.1978.03280480051020.

Hoogendoorn, S., Oosterbeek, H., \& Van Praag, M. (2013). The impact of gender diversity on the performance of business teams: Evidence from a field experiment. Management Science, 59(7), 1514-1528.

Huang, X., Shi, K., Zhang, Z., \& Cheung, Y.L. (2006). The impact of participative leadership behavior on psychological empowerment and organizational commitment in Chinese state-owned enterprises: The moderating role of organizational tenure. Asia Pacific Journal Manage. 23(1): 345-357. doi: 10.1007/ s10490-006-9006-3.

Ilmarinen, J. (1999). Ageing Workers in the European Union Status and Promotion of Work Ability. Employability and Employment. Helsinki: Finnish Institute of Occupational Health.
Inmyxai, S., \& Takahashi, Y. (2010). The effect of firm resources on business performance of male- and femaleheaded firms in the case of Lao micro-, small-, and medium-sized enterprises. International Journal of Business and Information. 5(1): 6390.

Iqbal, N., Ahmad, N., \& Javaid, K. (2013). Impact of employee empowerment on employee's performance in the context of banking sector of Pakistan, Pinnacle Business Management, 1(1), 1-6.

Ivancevich, J. M., Konopaske, R., \& Matteson, M. T. (2011). Organizational Behavior and Management (6 ${ }^{\text {th }}$ Ed.). New York, NY: McGrawHill Irwin.

Jankingthong, K. \& Rurkkhum, S. (2013). Factors affecting employ performance: A review of literature. Silpakorn University Journal of Social Sciences, Humanities, and Arts. 12(2), 115-127.

Kariuki, L.N., and Wekesa, S. (2018). Influence of human resource development practices on performance of academic staff in technical training institutions in Kenya: A case study of thika technical training institute, International Journal of Scientific and Research Publications, 8(9), 428-433. DOI: 10.29322/ IJSRP.8.9.2018.p8159.

Katozai, M.A. (2005). A Comprehensive Study of Education for Prospective Headmasters and Headmistresses University Publisher. Peshawar: Doger Unique Book.

Kaymakç, K., \& Babacan, S. (2014). Employee empowerment in new public management approach and a research, European Journal of Research on Education, 2(Special Issue), 62-70. 
Khuong, M.N. \& Yen, V.H. (2016). Investigate the effects of job stress on employee job performance: A case study at Dong Xuyen Industrial Zone, Vietnam. International Journal of Trade, Economics and Finance. 7(2), 31-37. doi:10.18178/ ijtef.2016.7.2.495.

Kimmel, M.S. (2000). The Gendered Society. Oxford: Oxford University Press.

Korabik, K., Lero, D.S., \& Whitehead, D.L. (2008). Handbook of Work and Family Integration: Research, Theory, and Best Practice. Burlington, MA: Elsevier.

Kotur, B.R., \& Anbazhagan, S. (2014). Influence of age and gender on the performance, IOSR Journal of Business and Management, 16(5), 97-103.

Lanzi, D. (2007). Capabilities, human capital, and education. Journal of Socio-Economics. 36(1), 424-435. Doi:10.1016/j.socec.2006.12.005.

Lepak, D.P. \& Snell, S.A. (1999). The human resource architecture: Toward a theory of human capital allocation and development. Academy of Management Review. 24(1): 31-48. Doi:10.5465/AMR.1999.1580439.

Marisa, S. \& Sonia, A. (2005). Linking organizational resources and work engagement to employee performance and customer loyalty: The mediation of service Climate. Journal of Applied Psychology. 90(6), 1217-1227. Doi:10.1037/ 0021-9010.90.6.1217.

Meenakshi, S. (2017). The impact of work life balance of faculty members in the private universities: An empirical study, Journal of Advanced Research in Dynamical \& Control Systems, 15Special Issue, 686-696.
Menon, S.T. (2001) Employee empowerment: An integrative psychological approach. Applied Psychology: An International Review, 50(1), 153-180.

Micheli, P. \& Neely, A. (2010). Performance measurement in the public sector in England: Searching the golden thread. Public Administration Review. 70(4), 591$600 . \quad$ Doi: $10.1111 / \mathrm{j} .1540-6210$. 2010.02180.x.

Moore, D.P. (1999). An examination of present research on the female entrepreneur-suggested research strategies for the 1990s. Journal of Business Ethics. 9(4), 275-281. Doi:10.1007/BF00380327.

Mujtaba, B.G., \& Kaifi, B.A. (2008). Afghan and American professional's leadership orientation toward tasks and relationships: Are there tendencies toward convergence or divergence?, Fortune Journal of International Management. 5(1), 107-125.

Nsubuga, Y.K. (2009). Analysis of leadership styles and school performance of secondary schools in Uganda. Doctoral Thesis. Port Elizabeth-Uganda: Department of Education, Nelson Mandela Metropolitan University.

Orser, B. \& Foster, M. (1992). Home Enterprise: Canadians and HomeBased Work. Canada: The HomeBased Business Project Committee.

Osborn, D. \& Gabler, T. (1992). Reinverting Government: How the Entrepreneurial Spirit is Transforming the Public Sector. AddisonWesley. 
Ozaralli, N. (2003). Effects of transformational leadership on empowerment and team effectiveness, Leadership and Organization Development Journal. 24(6), 335344.

Plauché, W.C. \& Miller Jr., J.M. (1986). Performances of female medical students in an obstetrics and gynecology clerkship. Journal of Medical Education. 61(1), 323-325.

Pratama, A., Bahtera, H., Anggara, B.Z., \& Yolanda, V. (2010). Focus Group Discussion Report on Consumer Purchase Decision of Laptops and Netbooks, Unpublished Working Paper.

Rajalingam, Y., Jauhar, J., \& Bashawir, A.G. (2015). A study on the impact of empowerment on employee performance: The mediating role of appraisal, International Journal of Liberal Arts and Social Science, 3(1), 92-104.

Rajasekar, D., Sudheer, A.K., \& Reddy, P.R. (2017). A study on employee empowerment in Indian corporate sector, International Journal of Civil Engineering and Technology, 8(11), 268-277.

Ravichandran, M. \& Indumathy, J. (2018). Influence of socio-economic and demographic factors on stress perception and attitude towards self and job: A study with reference to women health care professionals, Anthropologist 32(1-3), 16-22.

Rivai, V. 2006. Manajemen Sumber Daya Manusia Untuk Perusahaan dari Teori ke Praktik. Jakarta: PT Raja Grafindo Persada.

Robbins, S.P. \& Judge, T.A. (2008). Organization Behavior $\left(15^{\text {th }}\right.$ ed.). Boston: Pearson.
Robbins, S.P. (2006). Organizational Behavior: Concept, Controversies and Application. New Jersey: Prentice Hall.

Roflin, E. (2009). Penggunaan metode trimming pada analisis jalur dalam menentukan model kausal dana alokasi umum kabupaten/kota di Provinsi Sumatera Selatan. Jurnal Penelitian Sains. 9(12), 1-9.

Samad, S., \& Yusuf, S.Y.M. (2014). effects of personality traits, organizational factors and demographic variables on employee empowerment, Australian Journal of Basic and Applied Sciences, 8(2), 284-293.

Sankar, R. (2018). A study on employee empowerment, work performance and its allied factors among teaching and non-teaching women staffs in Puducherry. International Journal of Management Studies. 5(1), 21-27. Doi: 10.18843/ijms/v5i1(2)/04

Sankar, R. (2018). Gender, Work Performance and Workers Empowerment: A Statistical Interrogation, International Journal of Management Studies, 5(3), 27-39. Doi: 10.18843/ijms/v5iS3/03

Spreitzer, G.M. (1995). Psychological empowerment in the workplace: Dimensions, measurement, and validation. Academy of Management Journal, 38(5), 1442-1465.

Spreitzer, G.M., Kizilos, M.A., \& Nason, S.W. (1997). A dimensional analysis of the relationship between psychological empowerment and effectiveness, satisfaction and strain. Journal of Management, 23(5), 679704

Srivastava, A.K. (2008). Effect of perceived work environment on employees' job behaviour and organizational effectiveness. Journal of the Indian Academy of Applied Psychology. 34(1): 47-55. 
Sumodiningrat, G. (2002). Pemberdayaan Masyarakat dan Jaring Pengaman Sosial, Jakarta: Gramedia.

Takur, G. (2017). The influence of demographic characteristics on performance of academic employee in Kenyatta University, Proceedings of the Thirteenth Asia-Pacific Conference on Global Business, Economics, Finance and Banking (AP17Singapore Conference). Singapore. 3-5, August 2017, pp. 1-16.

Trusty, J. \& S.G. Niles. (2004). Realized potential or lost talent: High school variables and bachelor's degree completion. Career Development Quarterly. $\quad 53(1)$ : 2-15. Doi:10.1002/j.21610045.2004.tb00651.x.

Tuckman, B.W. (1999). A Tripartite Model of Motivation for Achievement: Attitude, Drive, Strategy. New York: John Wiley \& Sons Inc.

Ukil, M.I. (2016). The impact of employee empowerment on employee satisfaction and service quality: Empirical evidence from financial enterprises in Bangladesh, Business: Theory and Practice. 17(2), 178-189.

Van Vugt, M. (2006). Evolutionary origins of leadership and followership. Personality \& Social Psychology Review. $\quad$ 10(4): 354-371. Doi:10.1207/s15327957pspr1004_5.

Vinod, H. \& S.K. Kaushik. (2007). Human capital and economic growth: Evidence from developing countries. American Economist. 51(1): 29-39. Doi:10.1177/056943450705100103.

Warr, P. (1994). Age and job performance. In J. Snel \& R. R. Cremer (eds.), Work and Aging. A European Perspective (pp. 309322). London: Taylor \& Francis.
Yilmaz, O.D. (2015). Revisiting the impact of perceived empowerment on job performance: Results from front-line employees, Turizam. 19(1), 34-46.

Zani, B. \& Pietrantoni, L. (2001). Gender differences in burnout, empowerment and somatic symptoms among health professionals: Moderators and mediators. Equal Opportunities International. 20(2), 39-48. 